\title{
Rosai-Dorfman betegség
}

\section{Rosai-Dorfman disease}

\author{
TÖRÖK LÁSZLÓ DR. ${ }^{1}$, BAGDI ENIKŐ DR. ${ }^{2}$, KOCSIS LAJOS DR. ${ }^{3}$, \\ KRENÁCS LÁSZLÓ DR.²
}

\author{
Megyei Kórház Bôrgyógyászat ${ }^{1}$, Patológia ${ }^{3}$ Kecskemét, Daganatpatológiai és Molekuláris \\ Diagnosztikai Laboratórium², Szeged
}

\section{ÖSSZEFOGLALÁS}

A Rosai-Dorfman betegség, vagy sinus histiocytosis massziv lymphadenopátiával, olyan benignus, reaktív histiocyta proliferáció, amely primeren a nyirokcsomókat érinti. Gyakori az extratranodális részvétel, amelyek között a bör manifesztáció a leggyakoribb. A szerzók olyan érdekes esetet mutatnak be, ahol a klinikai lefolyás során a börtünetek domináltak. Kiváltó tényezóként infekció és malignus daganat volt feltételezhetô, a lefolyás során pedig spontán gyógyulást észleltek.

\section{Kulcsszavak: \\ Rosai-Dorfman betegség - bôrtünetek - spontán gyógyulás}

\section{SUMMARY}

Rosai-Dorfman disease or sinus histiocytosis with massive lymphadenopthy is a benign, reactive histiocytic (macrophage related) proliferation that involves primarily the lymph nodes. Extranodal involvement is common of which the skin manifestation is the most frequent. An interesting case is reported where during the clinical course the skin symptoms dominated. As a trigger infection and malignant tumor occurred and during the course spontaneous recovery could be seen.

\section{Key words: \\ Rosai-Dorfman disease - skin manifestation - spontaneous recovery}

Juan Rosai és Ronald Dorfman 1969-ben 4 fiatal betegen "Sinus histiocytosis with massive lymphadenopathy” névvel új kórképet írtak le. A betegséget klinikailag fájdalmatlan, cervicális lymphademegália, láz és fogyás, laboratóriumilag fokozott vvt süllyedés, anaemia, leukocytosis és hypergammaglobulinaemia, szövettanilag a nyirokcsomók sinusainak kitágulása és nem neoplasztikus histiocyta proliferáció jellemzi (1). Olyan ritkább felnőttkori esetet ismertetünk, ahol a klinikai tünetek közül a kiterjedt bőr érintettség dominált.

Közleményünket Prof. Dr. Pastinszky István emlékére ajánljuk.

\section{Esetismertetés}

A 60 éves férfibeteg anamnézisében 2005-ben egy megnagyobbodott hasi nyirokcsomó szövettani vizsgálata kapcsán csak obszervációt igénylő chrónikus lymphocytás leukaemia (RAI I. stádium) szerepel. 2011. áprilisban lázzal járó felsô légúti betegség miatt antibiotikummal kezelték, amely során testszerte kiütések léptek fel. A bőrtüneteket gyógyszerallergiának tartották. 2011 májusában, amikor a ,gyógyszerallergiás” kiütései még jelen voltak, a hát közepérôl melanoma került eltávolításra (tumor vastagság $1,3 \mathrm{~mm}$, mitózis ráta $3 / \mathrm{mm}^{2}$ ). Sentinel node biopsia történt, de a megnagyobbodott hónalji nyirokcsomóban melanoma metasztázis nem volt kimutatható. A nyirokcsomók további vizsgálata a B-sejtes chrónikus lymphoid leukaemia jelenlétét igazolta. Emellett egyes subcapsuláris sinusokban nagy, S-100 pozitív, histicyter sejtek voltak láthatók, melyek citoplazmájában lymphocyták invaginálódtak (emperipolesis). A látottak a Rosai-Dorfman betegségre karakterisztikusak (1. ábra).

Dermatológiai státusza ekkor a következô volt: a törzsön és végtagok proximális részein nagyszámú, élénkvörös, 1-4 mm nagyságú, többnyire különálló, monomorf, papulosus exanthaema (2 - 4 . ábra). A felszínes nyirokcsomók nem voltak tapinthatók. A bốr szövettani vizsgálata a dermisben az epidermist előboltosító, atípusos lymphohistiocyter infiltrátumot mutatott. Az infiltrátum sejtjeinek többsége nagy, histiocyter sejtalak bőséges amphophil cytoplasmával és relatíve nagy kerekded maggal. Immunmorfológiailag a nagy sejtek CD68 (pan -makrofág marker)), S-100 fehérje pozitívak és XIII faktor antigén, CD30 negatív fenotípusúak. Ezen nagy sejtek cytoplasmájában szintén lymphocyták és szegmentált magvú granulocyták invaginációja látható (5 ábra). A nyirokcsomók szövettanát figyelembe véve a látottak a Rosai-Dorfman betegség bőr manifesztációját bizonyították chronikus lymphoid leukaemiás betegen.

A további célzott részletes vizsgálatokból: agyi MR, MRTG, hasi UH, csontszcintigraphia, szemészeti-, fül-orr-gégészet és laboratóriumi vizsgálat csak a $47 \mathrm{~mm} / \mathrm{h}$ vvt. szedimentáció, enyhe leukocytosis $(10.58 \mathrm{G} / \mathrm{L})$, kissé fokozott gammaglobulin szint emelkedés (ELFO: gamma: 19,5\%) és az átvészelt EBV fertôzést mutató szerológia érdemel említést. Egyéb extranodális manifesztációt nem találtunk. Tekintettel a negatív vizsgálati eredményekre és a beteg panaszmentességére a beteget megfigyeltük. Kilenc hónapos követés után a bőrtünetek spontán gyógyultak. 

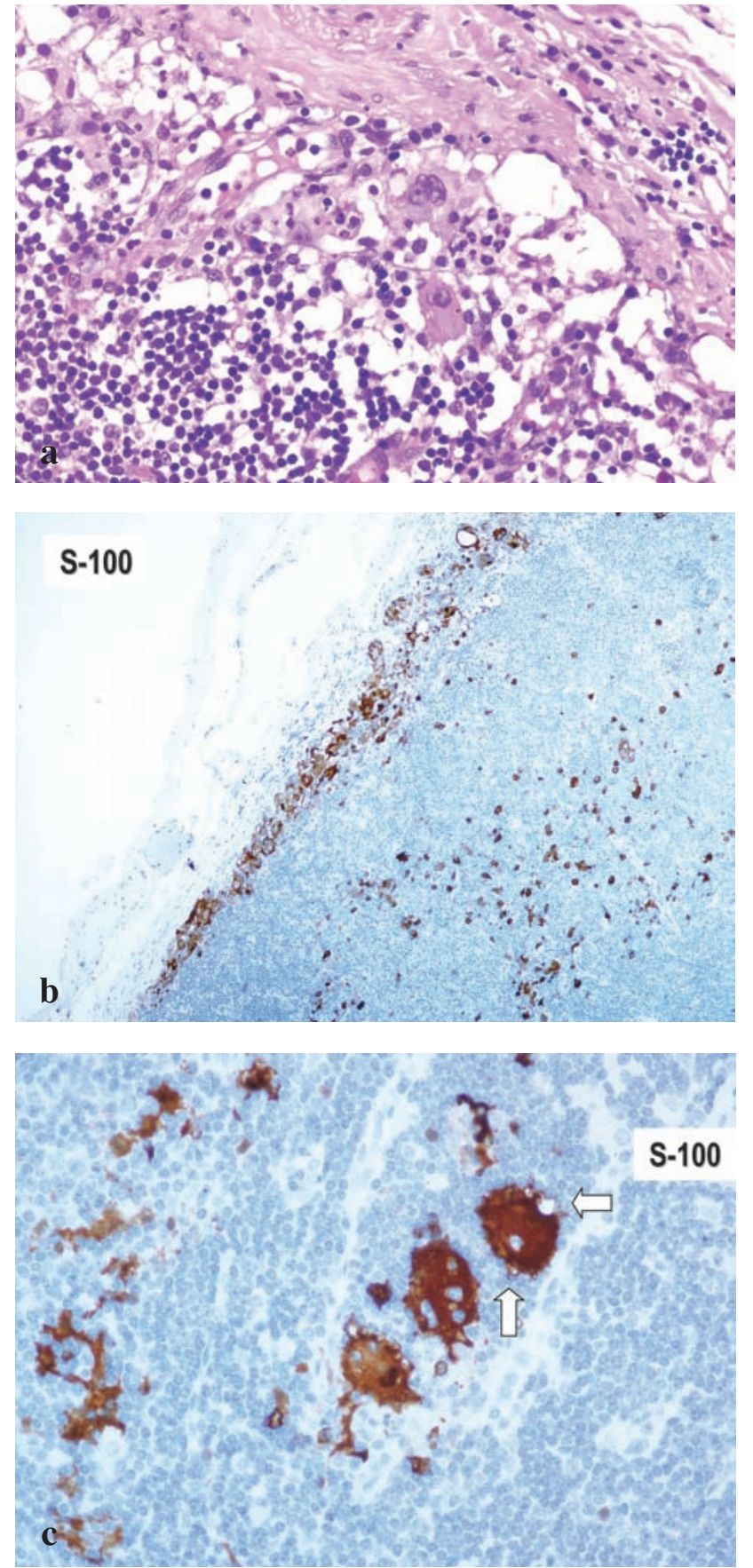

\section{1. ábra}

Rosai-Dorfman betegség nyirokcsomóban. A nyirokcsomó sinusokban nagy, atípusos histiocyter sejtek látszanak S-100 fehérje pozitivitással.

a: HE: $x 400$, b: S-100: $x 100$, c: S-100: $x 400$, a fehér nyíl az emperipolezisre mutat

\section{Megbeszélés}

A histiocyter betegségek a legújabb WHO klasszifikációja szerint a Rosai-Dorfman betegség a makrophagokkal kapcsolatos kórképek alcsoportjába tartozik (2). Etiopatogenezise nem ismert. Feltételezhetô, hogy patológiás immunválasz által kiváltott specifikus histiocyta akkumulációról és aktiválódásról lehet szó. A folyamat reaktív jelle-
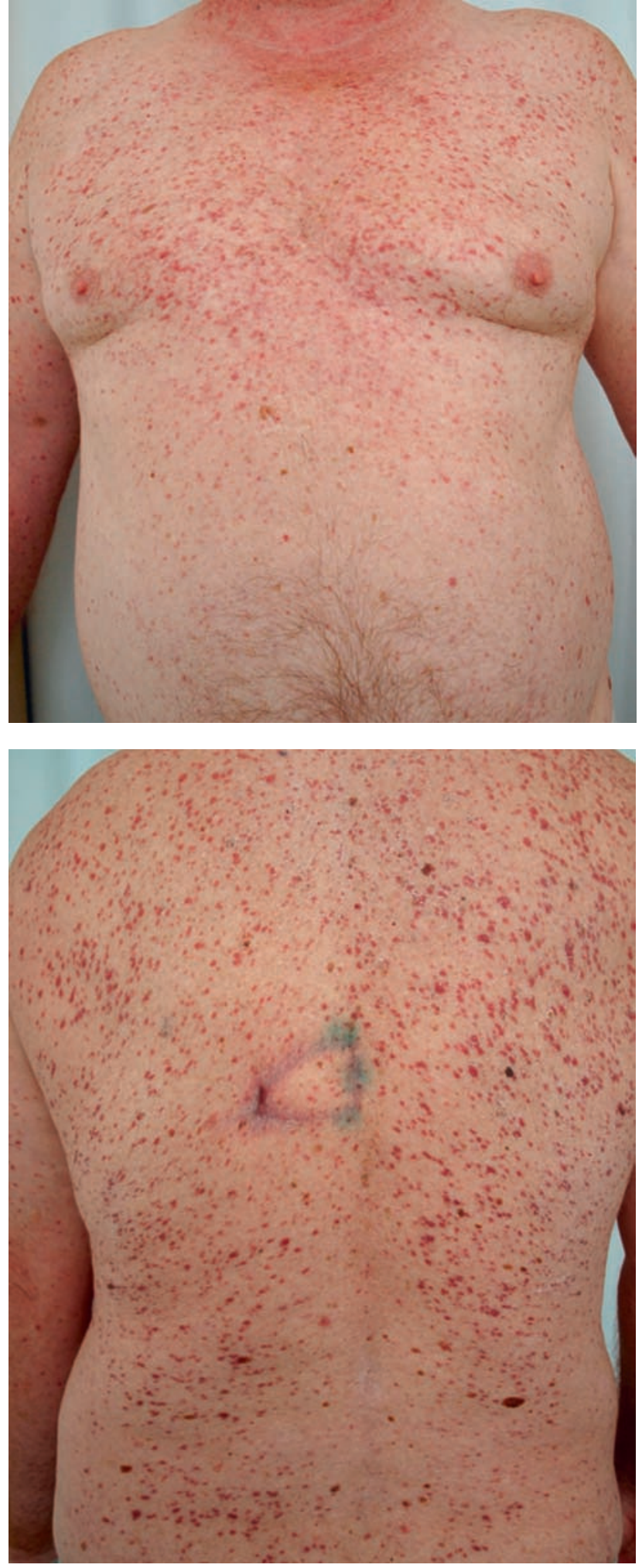

\section{2., 3. ábra}

Élénkvörös, monomorph, papulosus exanthema

gú, amelynek hátterében különböző triggerek lehetnek, mint pl. vírus infekciók. A szisztémás formáknál HHV-6 és 8, HSV, EBV, parvo vírus B19, míg a lágyrész formáknál a polyoma vírus SV40. Immunológiai kiváltó okként autoimmun betegségek, lymphoma, leukaemia és HIV infekció, ritkán a cután formánál vaccináció jöhet szóba (3-5). 


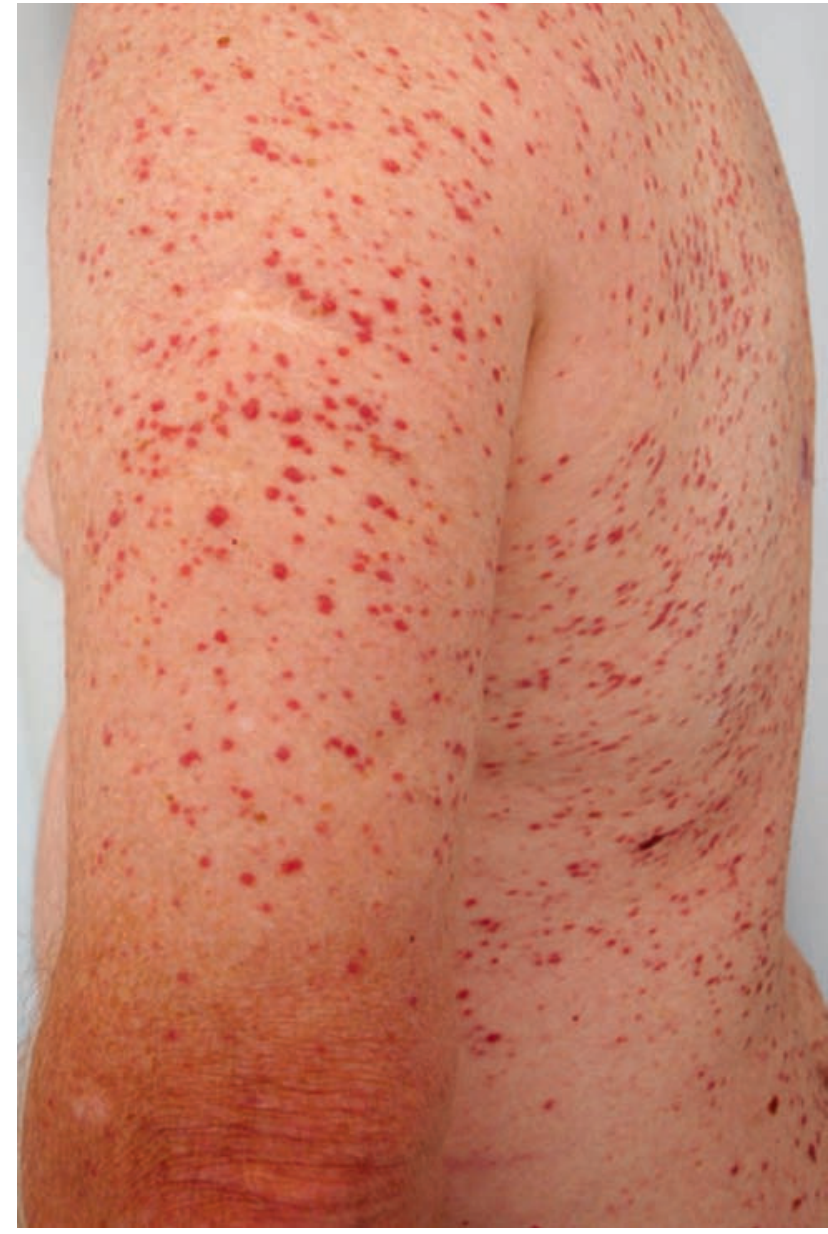

4. ábra

Élénkvörös, monomorph, papulosus exanthema
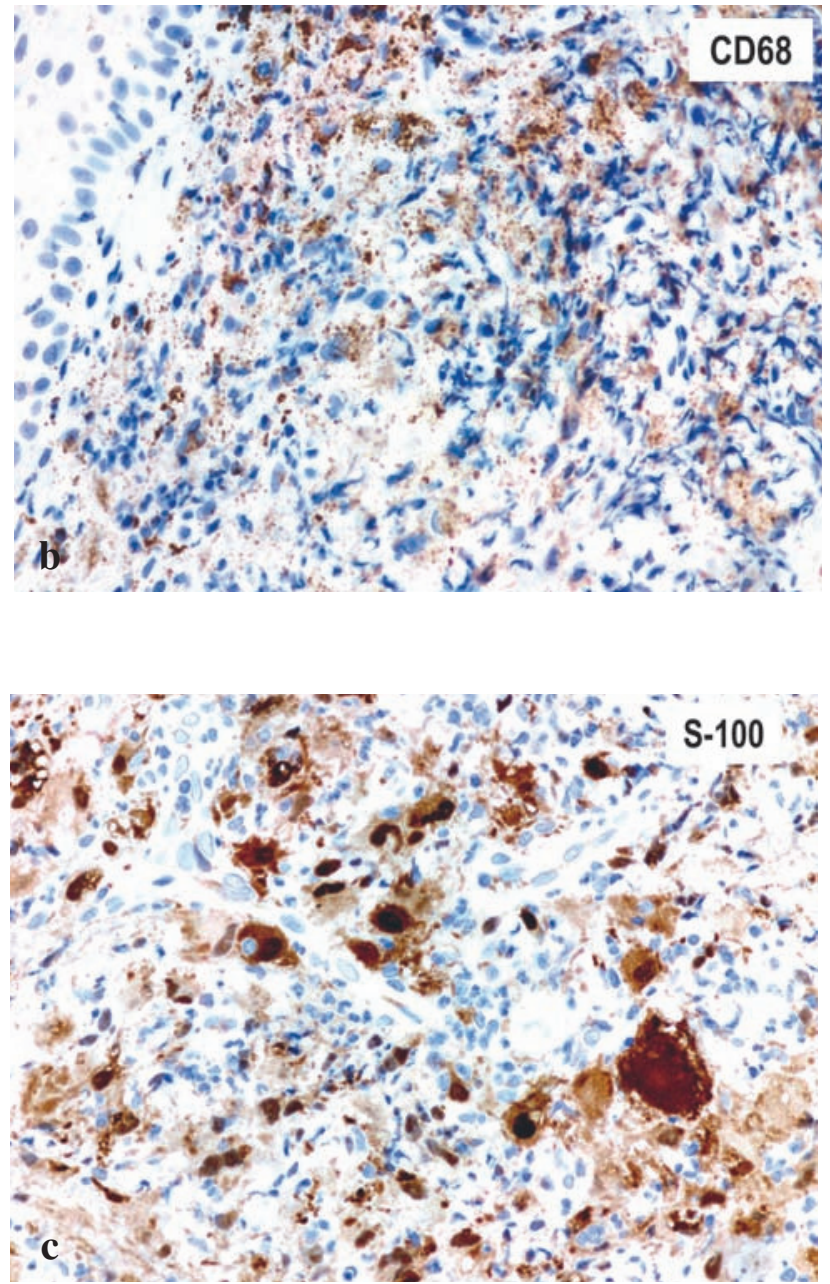
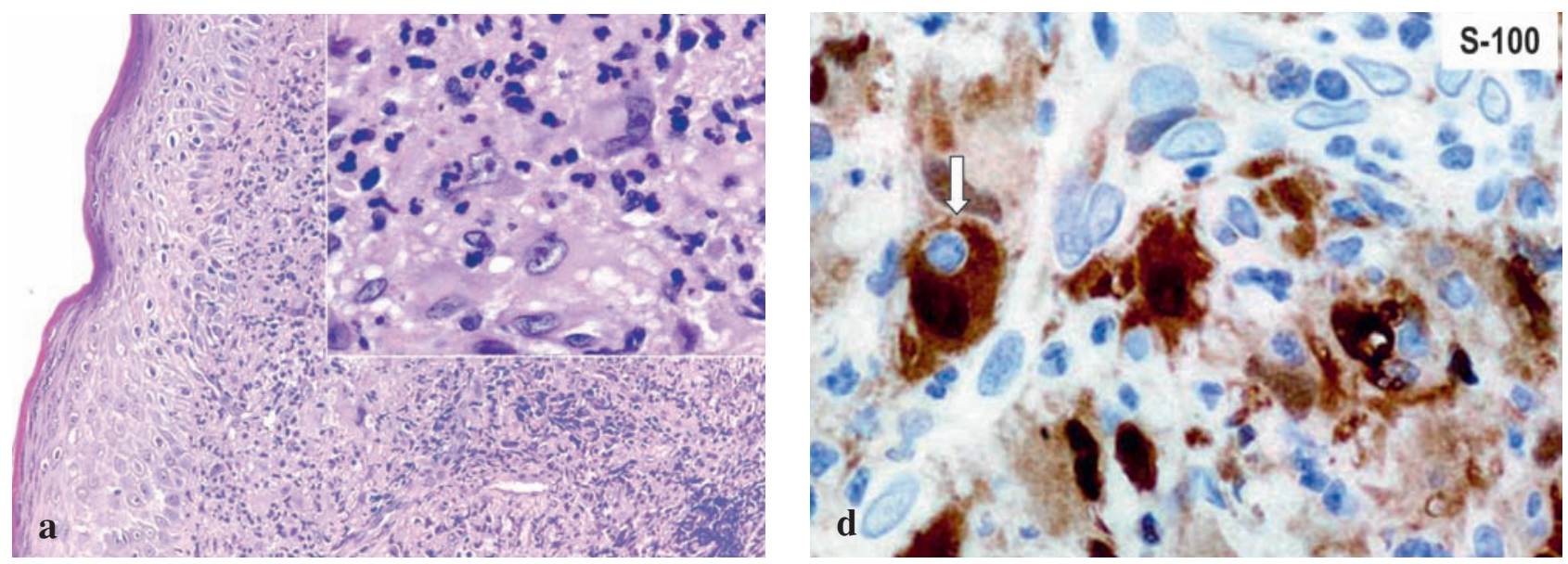

5. ábra

Rosai-Dorfman betegség bőr infiltrátuma: S-100 és CD68 pozitív lezionális histiocyter sejtek az irhában. a: HE: x200 betét: x1000, b: CD68: x200, c: S-100: x400, d: S-100: x1000

A betegség első leírása utáni közlemények az extranodális manifesztációk társulására hívták fel a figyelmet, amelyek az esetek mintegy 40\%-ban fordultak elő (6). Ezért a kórkép elnevezésére újabban a Rosai-Dorfman betegség nevet ajánlják, amely terminológia jobban kifejezi az extranodális manifesztációkat (7). A leggyakoribban érintett extranodális szervek: a bőr, felső légutak, orbita és a csontok, de ritkán a genitourinális szervek, az alsó respiratorikus traktus, szájüreg, nyálmirigyek, központi idegrendszer és a lágy szövetek is részt vehetnek a folyamatban (3).

Szövettanilag a betegségre karakterisztikus a nagy, halványan festődő, polygonalis S-100 és CD68 pozitív histi- 
ocyták proliferációja és a hístíocyták cytoplazmájában lévô intakt lymphocyták, ritkábban vörösvérsejtek ill. leukocyták jelenléte, az emperipolesis. Ezeket a sejteket hívják Rosai-Dorfman sejteknek is (1).

Az extranodális részvételnél legtöbbször bőrtünetekkel találkozhatunk, mintegy 11\%-ban. Ezek leggyakrabban a fej-nyaki régióban, a megnagyobbodott nyirokcsomók kőrnyékén lévő vörös vagy barnás színú plakkokban, csomókban nyilvánulnak meg, amelyeket rendszerint satellita papulák vesznek körül. Érintve lehet továbbá a törzs és a végtagok proximális része. Ilyenkor rendszerint disszeminált, panaszt nem okozó, vörös, ritkábban barnás, vagy sárgás színú papulákat, kisebb- nagyobb csomókat ill. plakkokat látunk $(4,8,9,10,11,12)$.

A betegség kiterjedése alapján a Rosai-Dorfman betegség következő formái különíthetôk el. 1. Szisztémás Rosai-Dorfman betegség. 2. Lágyrész Rosai-Dorfman betegség és 3. Cutan Rosai-Dorfman betegség. A tisztán cutan forma az esetek mintegy 3\%-ban fordul elő. A cután formát újabban többen külön klinikai entitásnak tartják a szisztémás, ill. a nodális tünetek hiánya miatt. A tisztán cután forma diagnosztizálásánál azonban figyelembe kell venni, hogy rejtetten szisztémás léziók is lehetnek, amelyek csak késóbb manifesztálódhatnak (8).

A kórkép lefolyása indolens, gyakori a spontán gyógyulás, különösen a cutan formáknál. Több nyirokrégió, valamint több belsô szerv részvételénél, különösen a tüdő, máj, vese érintettsége és a társuló immunológiai zavarok súlyosabb lefolyásra utalnak, amely ritkán letális is lehet. A betegség az esetek felében spontán gyógyul. A szisztémás formák kezelésében használatos orális szteroidok a lymphadenomegáliát és a lázat csökkentik. A sugárkezelés csak korlátozottan hatékony, a kemoterápia ineffektív, a vitális szervek kompressziójánál sebészeti beavatkozásra lehet szükség. A cután tünetek kezelésére, az obszerváció mellett kryoterápia, radioterápia, lokális és szisztémás szteroid, ill. az exciso jöhet szóba $(3,8)$.

Esetünk több szempontból is érdekesnek tekinthetô. A klinikai képet a kiterjedt, disszeminált, papulosus bőrtünetek dominálták és a nyirokcsomók megnagyobbodása, a lymphoid leukaemia és a melanoma ellenére is, a háttérben maradt. A betegünknél két különböző típusú kiváltó tényezó is előfordult: infekció és daganat. Ha a melanoma miatt nem került volna sor nyirokcsomó eltávolításra, esetünket cután Rosai-Dorfman betegségnek minősíthettük volna. Ez a cután formák diagnosztizálásának buktatóira hívja fel a figyelmet. Továbbá megemlítendő, hogy a két malignus daganat társulása ellenére is betegség spontán gyógyult.

\section{IRODALOM}

1. Rosai J., Dorfman R. F.: Sinus histiocytosis with massive lymphadenopathy. A newly recognised benign clinicopathological entity. Arch Pathol. (1969) 87, 63-70.

2. Jaffe R., Weiss L. M., Facchetti F.: Tumours derived from Langerhans cells. In: World Health Organization Classification of Tumours of Haematopoietic and Lymphoid Tissues, Swerdlow SH, Campo E, Harris NL, et al (Eds), IARC Press, Lyon 2008. p. 358.

3. Hsian C. H., Tsai T. F., Yang T. H. mtsai.: Clinicopathologic Characteristics of Rosai-Dorfman Disease in a Medical Center in Northern Taiwan. J Formos Med Assoc (2006) 105, 701-707.

4. Al-Duraji W., Anandan A., Klassen-Fischer M. mtsai.: Soft tissue Rosai-Dorfman disease: 29 new lesions in 18 patients with detection of polyomavirus antigen in 3 abdomanial cases. Annals of Diagnostic Pathology. (2010) 14, 309-316.

5. Bassis V. A., Fairley J. A., Ameln R. mtsai.: Cutaneous RosaiDorfman disease following pneumococcal vaccination. J Am Acad Dermatol. (2011) 65, 890-892.

6. Molina-Garido M. J., Guillén-Ponce C.: Extranodal RosaiDorfman Disease with Cutaneous and Periodontal Involvement: A rare presentation. Case Rep Oncol. (2011) 4, 99-100.

7. Foucar E., Rosai J. Dorfman R.: Sinus histiocytosis with massive lymphadenopathy (Rosai-Dorfman disease): review of the entity. Semin Diagn Pathol, (1990) 7, 19-73.

8. Wang K. H., Chen W. Y., Liu H. N. mtsai.: Cutaneous RosaiDorfman disease: clinicopathological profiles, spectrum and evolution of 21 lesions in six patients. Brit J Dermatol. (2006) 154, 276- 286.

9. Pappo E., Scgupbach A., Worobe S. M.: Cutaneois RosaiDorfman Disease: a case report. Dermatology Online Journal (2012) 18 (11), 6.

10. Fening K., Bechtel M., Peters M.: Cutaneous Rosai-dDorfman Disease Persisiting After Surgical Excision. Clinical-Aesthetic Dermatology (2010) 9, 34-36.

11. Sagi M., Marcus B. S., Gat A. mtsai.: A 60-year-old women with subcutaneous nodules on the thigh. Clin Exp. Dermato. (2012) 37, 448-449.

12. Szepessy Zs., Diczházy Cs., Szamosi A.: Rosai-Dorfmanszindróma - esetismertetés. Szemészet (2008) 145, 64-67.

Érkezett: 2013. 06. 19.

Közlésre elfogadva: 2013. 09. 03.

A Bőrgyógyászati és Venerológiai Szemle Szerkesztôsége fenntartja magának a jogot a hirdetések és szponzorált közlemények elfogadására, de ezek tartalmáért semmilyen körülmények között nem vállal felelősséget. 